documents and the solicitation of bribes.

2. It provides that "trade custom" shall not be admissible or constitute a defense.

3. It provides immunity under the law to the person who shall first report the fact, under oath, to a federal district attorney. Thus it breaks up the conspiracy of silence between bribe giver and bribe taker that other commercial bribery laws enforce on both parties, and makes the law, through fear of exposure, a preventative measure.

4. It provides for a fine or imprisonment for proven breaches of the act.

\section{Aroused Business Sentiment}

Excellent and practical as are the provisions of this proposed federal law, the Commercial Standards Council appreciates fully that American business must clean its own house. The law is a broom for this purpose, but the broom must be wielded by the force of public opinion. The Council is, therefore, collecting facts and figures about commercial bribery. It is showing American business men the commercial shortsightedness and the dishonesty of the practice. It is rousing the better business sentiment of the country. American business today faces a hard task. Economic readjustment has brought tremendous competition. In many industries there must be great curtailment of production unless export trade is developed, and this must be developed in spite of a war-won, undeserved reputation for sharp dealing. American business is freer from dishonesty and malpractice than most national commerce. An American business man, A. T. Stewart, gave to the world a fixed price in retail stores, abolishing haggling barter and discouraging completely the age old proverb: "Let the buyer beware." Known prices are the rule-not the exception-in most branches of American trade. American business has abolished the giving of secret rebates against transportation charges. American business has established advertising and salesmanship upon an honest basis of efficiency not known elsewhere in the world. Through the Commercial Standards Council, the right consciousness for fair dealing, inherent in the average American business man, has the opportunity for expression and for organized effort to establish higher business ethics.

\title{
A Simple Code of Business Ethics
}

\author{
By Edward A. Filene \\ President, William Filene's Sons Company, Boston, Massachusetts
}

GOOD will is one of the most imIt is dependent basically on the confidence of the public. Public confdence, in turn, depends upon the real service to the community that the business performs.

Because of the recognition of this fact, many sets of "business principles," often unwritten, have grown up.
There has developed, also, a code of business ethics that, though unformulated, has perhaps obtained somewhat general recognition. There seems to be need of a simple written code. I propose the following:

1. A business, in order to have the right to succeed, must be of real service to the community.

2. Real service in business consists 
in making or selling merchandise of reliable quality for the lowest practically possible price, provided that merchandise is made and sold under just conditions.

This is short and simple. At first glance it may appear insufficient. Yet a closer study will show that it covers the whole field of business ethics. Let me try to indicate a few of the possible bearings of this statement of principles and draw upon the experience of a lifetime to show why it is my firm conviction that it is not only allsufficient from an ethical standpoint, but is also the very best basis upon which the greatest just success in business can be attained. It covers all the degrees: to get on (positive); to get honor (comparative); to get honest (superlative).

In the first place, I say that one has not gained the right to success until he has made his business of real service to the community. Just because one has organized a company, built a factory or opened a store is no reason why the community owes him a living. He went into business voluntarily. He must justify success by doing something which merits compensation.

This would seem self-evident, and yet it is true that a great deal of business is done with no real comprehension of this axiomatic truth. If I take money from you without return service, by force or threat, I am legally a thief and a robber and can be arrested and put in prison. Likewise, if I take from you by fraud or false pretense, I can be dealt with legally. But under the common practice of today I can safely take from you, in return for merchandise, all that I can induce you to pay.

In reality, the difference between the last case and the first is not fundamental, the chief difference being that the last is done under the shield of custom. Ethically, unless the manufacturer and the merchant give an adequate return, unless they render a real service, they have no more right to a reward than has the robber or the cheat.

\section{"Real Service to the Community"}

At the first reading, the truth of the first part of the code, even though acceptable, may not seem to cover enough of the field. This will depend on the definitions given to the terms in the code. Let us examine the definition of service in the second sentence of the code. What constitutes "real service to the community?" Clearly it is not offering merchandise for sale at the greatest price which we believe can be obtained from the public. The work of the manufacturer consists in making goods which to his expert knowledge are best adapted for the particular uses for which people want them. The work of the merchant consists in obtaining merchandise in wholesale quantities and selling it in retail quantities at a just price.

The merchant who buys a pair of shoes and sells them for more than a fair advance over cost, performs no adequate service to the community and is ethically no more entitled to a profit than is the man who steals an automobile and sells it to some unsuspecting purchaser, or the man who makes adulterated goods and sells them for genuine. We would refuse to pay the bill of the physician, the carpenter or the man who shovels snow off the sidewalk, if he did not perform a service somewhere nearly equal to his charge. Should not the same demand for adequate service be made on the manufacturer, the merchant and the banker as on other servants of the community? But we pay the charges of a system of merchandising that, because of excessive expense in doing business and the charging of profit on the basis of such expense, adds, on the average, nearly 
or quite one hundred per cent to the production cost of the goods.

If one makes merchandising too expensive, if he exacts a profit greater than a just compensation for his work, then he ceases to serve the community. In so far as he makes profits beyond the value of the work performed, he becomes a parasite. The manufacturer or merchant who does not reduce business costs and profits to the lowest practicable figure, and so enable the community to obtain goods for as low a price as possible, is not serving the community to the best of his ability and consequently is not entitled to large rewards. It is his duty to sell his goods or merchandise at the lowest practicable price, including the lowest safe profit. His total profit must increase, not through large margins on few transactions, but through the number of people whom he serves and the number of times he serves them.

\section{"Lowest Practicable Price"}

But this is still not enough. Our code should furnish us something with which to measure this lowest practicable price. A price that is the "lowest practicable" in one place may not be so in another, and the lowest practicable price one year will probably not be the lowest practicable another year. Civilization started when a savage horde discovered that some one of the group could make sharper arrow heads than the others and gave him the task of making arrow heads for all the rest, promising, in return, to provide him with the necessaries of life. From then until now we have gone on progressively increasing the specialization of individuals and with every step of specialization and standardization we have reduced the total amount of work that humanity as a whole must do to maintain itself. Each improvement and refinement of this process makes each effort of each individual worth more, or, relatively, makes the things he needs or desires cheaper. We are blocking the march of civilization unless we can make ever cheaper and cheaper the goods we sell.

During a life-long experience in retail distribution, my views on the factors that go to make up real service, and their relative importance, have changed a number of times, but each change has brought me nearer to the conclusion that no real service can be rendered except as business makes the necessaries of life more and more accessible to the consumer, i.e., makes prices cheaper and cheaper. The greatest rewards of business in the past have gone to financial leaders. In the future, success will depend not so much on finance as on the ability to lead large numbers of employes so that they will produce successfully and cheaply. The basis of such success is harmonious conditions.

It should be axiomatic that the merchandise must be of reliable quality, for a lowering of prices through the substitution of inferior merchandise is not real progress. Surely we need not dwell on this point of the creed.

\section{"Just Conditions"}

Finally, the proposed code calls for merchandise made and sold under "just conditions." If one "serves" the community at the expense of any portion of it he has not added to the sum total of the community's welfare, but has been merely the means of depriving some of its members of benefits for the sake of distributing them to others. If a merchant handles merchandise that has been made under "sweat shop conditions," under "padrone" systems or by underpaid or overworked people, he is sinning ethically as well as economically; for either he is benefiting himself, or he is letting the rest of the com- 
munity benefit, at the expense of those workers.

Equally, a manager's treatment of his employes must be just. This is not the place to enlarge on the various methods that have been developed, chiefly during the last ten years, to ensure justice and pleasant relations inside the factory or shop. Too much thought and planning cannot be given to creating good relations between employer and employe, but in the endeavor to improve these relations the fact should not be lost sight of that such work is not an end in itself but merely a very important factor among the means for attaining the true aim of business - service to the community.

\section{The Business Man and His EMPLOYES}

I am in honor bound, as a decent citizen, to treat my employes as well as I know how. If I am to require of the city that it send my employes to my store in the morning fortified by education and health to do my work, I have assumed by that very requirement the duty of sending them out at night at least not deteriorated, and if I have any sense of honor I shall want to give good measure and try to send them out, so far as lies in my power, improved physically, financially and morally by their working hours.

Now, of course, this is a hard thing to do and, in fact, is not generally accomplished. But the failure to do it is always paid for indirectly and is more expensive and more onerous than the doing. Employes made friendly to their employers, through just treatment and good conditions, are much more likely to be useful and profit-producing employes than are those who work under bad conditions. Moreover, good relations between employers and employes leave the managers free for their proper work of planning and admin- istering the growth and success of the business.

We have been admonished to "love our neighbors as ourselves." Our real neighbors in these days of city life are not at all the people who happen to move in next door to us; our nearest neighbors are the people with whom we spend most of our waking hours. And with whom do we employers come in more continuous contact than with our employes? When once our thoughts run along this direction we see that there are many additional reasons for recognizing our employes as our nearest neighbors.

\section{“Neighborliness" and Its IMPLICATIONS}

With this consideration of my employes as my nearest neighbors and with the welfare of the business also urging me on, I soon found myself going outside of my store walls into city affairs. I was forced to associate myself with groups of other citizens who were trying to make the city a better one for my employes and myself to live in. This is justifiable; indeed, becomes essential, once the fact is recognized that our employes are our neighbors. We cannot let our neighbor pass in a rainstorm without offering at least a share of our umbrella, and when my employes came in wet from bad street car service I felt that I was only trying to be a good neighbor when I undertook to help reform that service. I therefore participated in the organization of a franchise league which for many years was influential in bettering the local service.

The same relationship in civic affairs forced me to help consolidate and reorganize the various business associations of the city. It led me to help create a City Club, where employers and employes and the friends of each could meet and learn to understand 
each other. Following this same impulse of duty to my neighborsmy employes-I finally came naturally into national and international work.

As I look back I find that each of these was, in itself, worth the time and effort it took', but, as my vision grew from these experiences, $I$ began to see that it was all a means to the big end, to the end of real service which, for a business man, is to enable people to buy cheaper and cheaper. This insight came late with me, and I am going to dwell on it because I find that it comes late with most men.

\section{Cheaper Prices the Way to Freedom}

The world is pretty well agreed now that, after all, its greatest progress will come from the greatest freedom to all men. While definite gains may be made by autocratic control of business yet, in business as in government, our experience has shown us that democracy is the safest road, and in spite of all its weaknesses it is the dominant political creed of today. Democracy is based on freedom. Freedom is not an eagle screaming on a crag, as we were told at Fourth of July celebrations at an impressionable age. The fundamental basis of freedom is the margin men have in their income over their outgo. No man is really free if he does not have more than enough with which to purchase the necessaries of life for his wife, his children and himself.

If a pair of shoes for the baby costs a day's work and a pair for each other member of the family costs from a day and a half to two days of work, a suit of clothes or a dress costs from five to seven days' work, monthly rent costs six to ten days' work, and so on, then the man who requires the work of every available day in the month to provide food, shelter and clothing for himself and his family is not free. There was a time when it cost a considerable fraction of a day's work to procure a drink of water; today, in the cities at least, water is so cheap that in this particular item men are free.

Under a code of ethics that requires business to sell cheaper and cheaper, the necessaries of life will be more easily obtained, and gradually the so-called luxuries of life will become more and more available for less and less hours or days of work; and thus men will become freer and freer.

The results of selling goods cheaper and cheaper show in the reduction of the number of hours of a day's work. Within a generation the working hours have gone down from sixteen to eight. There are enough indications and possibilities of further reductions in sight to make it not impossible that in time five hours' work a day will be sufficient to provide a living for a man with a family. This does not mean that a man will work only five hours, but rather that he need work only five hours for a mere living; many men under such circumstances will work eight or ten hours at their vocation, spurred on by the desire to put their children through college or to satisfy other desires. It will also leave the workers free to have an avocation besides-five hours for necessary work and five hours for that work to which they would give their whole time if they could afford it. Personally, I have always thought that preachers and teachers would do better work if they followed their professions only part time and some other vocation the rest of the time. This idea has been accepted in some schools.

\section{Conclusion}

I dare not follow this line of thought out into its ramifications, attractive as they appear, lest I be thought a dreamer 
instead of the shopkeeper that I am. Along this line, however, I believe lies the solution of many of the pressing economic questions of today which seem so hopelessly insoluble to many thoughtful citizens. It lies in making the products of business available at ever cheaper prices, and so permitting the great mass of the people to enjoy the full fruits of modern specialization and standardization. Mr. Ford has proved that this is not merely a philanthropic idea. The producer or the merchant who grasps the truth of this thought will in the end win a reward which is fairly his and which goes far beyond the dreams of the man who is in business for the profit alone.

One of America's foremost citizens lately said to me that in his opinion the security of the world depends in the last analysis on the way in which individuals conduct themselves. He said that the thing most needed was the will for service to the community, to the state, to the nation and to the world. Illustrating this point, he mentioned examples from his own experience showing that the progress of the world was retarded by selfishness, of which there was no better measure than the unnecessarily high prices charged for goods.

From the so-called "practical stand- point," also, I want to call attention to the fact that in these years of intense competition people are scanning prices as never before and buyers are going where they can buy the cheapest. Firms which cannot save their wastes of labor and material and meet this competition by selling cheaper and cheaper, will be forced out of business. Those that succeed will succeed on a bigger scale than ever before. They will sell greater and greater quantities with less and less expense and margin of profit on each item.

Mr. Ford has done this in his production. He has demonstrated in fact, and not merely in word, what the application of this idea does, in the case of an article which was a luxury when he took hold of it but became a necessity as he made it cheaper and cheaper. What is applicable to automobiles is applicable to any article demanded by the mass of the people.

So I say:

1. A business, in order to have the right to succeed, must be of real service to the community.

2. Real service in business consists in making or selling merchandise of reliable quality for the lowest practically possible price, provided that merchandise is made and sold under just conditions.

\section{Campaign of the International Association of Rotary Clubs for the Writing of Codes of Standards of Practice for Each Business and Profession}

\section{By Guy Gundaker}

Philadelphia, Pennsylvania, Chairman, Committee on Business Methods, International Association of Rotary Clubs

\footnotetext{
A ROTARY CLUB consists of men selected from each distinct business or profession, and is organized to accomplish:

First: The betterment of the individual member.
}

Second: The betterment of the member's business, both in a practical way and in an ideal way.

Third: The betterment of the member's craft or profession as a whole.

Fourth: The betterment of the mem- 